\title{
PENGARUH METODE SOROGAN TERHADAP KEMAMPUAN MEMBACA KITAB KUNING SANTRI DI PONDOK PESANTREN MAMBA'UL ULUM
}

\author{
Mukhlishotin \\ MTs Mambaul Ulum \\ Mukhlishotin90@gmail.com
}

\begin{abstract}
ABSTRAK
Guna meningkatkan efektifitas santri, guru/ustadz harus selalu berupaya dengan berbagai strategi, termasuk diantaranya adalah dengan menggunakan metode sorogan. Metode pembelajaran pada dasarnya merupakan pengelolaan dan pengembangan yang dilakukan terhadap komponen-komponen pembelajaran. Tujuan dilakukannya penelitian ini adalah: a) Untuk mengetahui penerapan metode sorogan di Pondok Pesantren Mambaul Ulum, b) Untuk mengetahui kemampuan membaca kitab kuning santri Pondok Pesantren Mambaul Ulum, c) Untuk mengetahui pengaruh metode sorogan terhadap keberhasilan dalam membaca kitab kuning santri di Pondok Pesantren Mambaul Ulum.

Penelitian ini merupakan penelitian lapangan dengan pendekatan kuantitatif dengan metode korelasi. Berdasarkan hasil penelitian yang telah dilakukan dapat disimpulkan bahwa metode sorogan memiliki pengaruh yang baik terhadap kemampuan membaca kitab kuning santri pondok pesantren Mambaul Ulum Wadang Ngasem Bojonegoro. Hal ini terbukti dari pengisian angket metode sorogan yang dihasilkan dari 30 responden dengan nilai rata-rata (85) pada kategori sangat baik dan nilai rata-rata raport membaca kitab fathul qorib kelas 3 ula dan 1 wustho $(79,5)$ jug a tergolong baik. Selanjutnya, untuk mengetahui pengaruh metode sorogan terhadap kemampuan membaca kitab kuning santri di pondok pesantren Mambaul Ulum Wadang Bojonegoro dalam penelitian ini digunakan metode analisis statistic Product Moment dan hasil dari rumusan Product Moment dapat diketahui bahwa nilai r sebesar 0,523.
\end{abstract}

\section{Kata Kunci: Metode Sorogan, Membaca Kitab Kuning.}

\section{PENDAHULUAN}

Metode pembelajaran dapat dianggap sebagai suatu prosedur atau proses yang teratur, suatu jalan atau cara yang teratur untuk melakukan pembelajaran. ${ }^{1}$ Pembelajaran akan menjadi efektifdan menyenangkan apabila metode yang digunakan sesuai dengan keadaan peserta didik dan tujuan belajar, sehingga materi lebih mudah di pahami oleh peserta didik atau santri di pesantren.

\footnotetext{
${ }^{1}$ Suyono, Belajar dan Pembelajaran, (Bandung: PT Remaja Rosdakarya, 2011), hlm. 19.
} 
Berdasarkan dengan metode, Al-Qur'an telah memberi petunjuk mengenai metode pendidikan secara umum yaitu dalam surat An-Nahl ayat 125 yang artinya berbunyi:

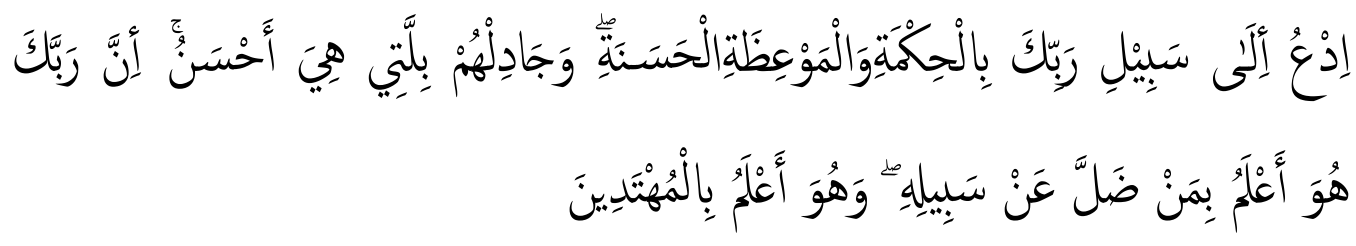

"seluruh (manusia) kepada jalan Tuhan-Mu dengan hikmah dan pelajaran yang baik dan bantahlah mereka dengan cara yang baik. Sesungguhnya Tuhan-Mu Dia-lah yang mengetahui tentang siapa yang tersesat dari jalan-Nya dan Dia-lah yang lebih mengetahui orang-orang yang mendapat petunjuk". ${ }^{2}(\mathrm{QS}$. An-Nahl : 125)

Berbicara tentang metode pembelajaran di pondok pesantren, ada banyak metode yang digunakan diantaranya adalah metode sorogan. Metode sorogan merupakan salah satu metode tradisional sekaligus metode andalan dalam pembelajaran bahasa Arab yang sampai saat ini masih saja di pertahankan di pondok pesantren Mambaul Ulum untuk mengatasi perbedaan tersebut. Metode sorogan sangat membantu dan mempermudah santriwan dan santriwati dalam memahami kitab kuning dan pemahaman nahwu shorof. ${ }^{3}$

Sebagai salah satu pesantren salafiyah yang ada di Bojonegoro, pondok pesantren Mambaul Ulum Wadang Ngasem Bojonegoro mewajibkan santriwan dan santriwatinya untuk mepelajari kitab kuning khususnya ilmu nahwu sharaf sebagai ciri khas dari pesantren Salafiyah. Dengan menguasai ilmu nahwu shorof akan sangat membantu memahami Al Qur'an dan Hadist.

Madrasah Diniyah di pondok pesantren Mambaul Ulum ada 6 kelas, nahwu hanya ada pada kelas 2-5. Kelas 1 adalah sekolah persiapan yang mana di kelas hanya di ajarkan ilmu dasar dalam seperti halnya bersuci dan lain lain. Pada kelas 2 santriwan dan santriwati mulai mempelajari ilmu nahwu shorof dan menerapkan teori dasar dari membaca kitab kuning, dan berkembang pada materi selanjutnya. hal. 417

${ }^{2}$ Departemen Agama RI, Al-Qur'an dan Tafsirnya, (Jakarta:Departemen Agama RI, 2006), Cet. 1,

${ }^{3}$ Observasi di pondok pesantren Mambaul Ulum yang menggunakan metode sorogan pada tanggal 27 Februari 2019 
Hasil observasi dilapangan banyak dari santriwan dan santriwati yang mempunyai kemampuan diatas rata-rata dalam mempelajari kitab kuning di kelas. Begitupun juga ada santriwan dan santriwati yang lemah dalam memahami kitab kuning, karena pembelajaran dikelas tidak merata dalam memahami kitab kuning sehingga guru harus menerangkan kembali sebelum melanjutkan ke materi selanjutnya. ${ }^{4}$

Berdasarkan temuan di lapangan penulis menyadari sangat pentingnya metode sorogan dalam mencapai tujuan pengajaran yang telah diterapkan. Membaca dan memahami kitab kuning adalah salah satu tujuan pengajaran di Madrasah Diniyah Mambaul Ulum, maka penulis tertarik untuk mengetahui bagaimana proses Pembelajaran kitab Kuning menggunakan metode sorogan di Pondok pesantren Mambaul Ulum Wadang Ngasem Bojonegoro.

\section{PEMBAHASAN}

\section{Penerapan Metode Sorogan di Pondok Pesantren Mambaul Ulum}

Pembelajaran sorogan di Pondok Pesantren Mambaul Ulum diterapkan setelah sholat Isya didalam Masjid'. Dalam proses belajar mengajar metode sorogan, karena pembelajarannya ini dilaksanakan di luar jam pelajaran diniyah maka pembelajaran ini dibagi menjadi dua kelompok yang satu kelompok putra dan satu kelompok putri. Kelompok putra dipegang K.H. Hanif Abdurrahman, sedangkan kelompok putri dipegang oleh Ustadz Abdul Mufid.

Pembelajaran metode sorogan yang diterapkan di pondok pesantren Mambaul Ulum ini mempunyai beberapa langkah secara umum yakni a) santri menghadap kepada kyai satu persatu dengan ketentuan sebagai berikut: 1) kyai membaca dan santri mendengarkan. 2) Kyai memberi perintah kepada santri untuk mengulangi bacaan yang akan disetorkan. 3) santri mendatangi ustadz supaya mendengarkan bacaan santri. b) Kyai melakukan monitoring dan koreksi seperlunya untuk mengetahui kesalahan dan kekurangan atas bacaan yang telah dibaca santri lalu kemudian kyai membetulkannya. ${ }^{5}$

\footnotetext{
4 Abdul Mufid Ustad Pondok Pesantren Mambaul Ulum, wawancara pribadi, pada tanggal 28 Februari 2019

${ }^{5}$ Abdul Mufid Ustadz Pondok Pesantren Mambaul Ulum, wawancara pribadi, pada tanggal 1 Mei 2019
} 
Metode pembelajaran sorogan ini dilaksanakan setelah sholat Isya' sampai pukul 21.30 WIB. Setiap santri harus menghadap kyai/ustadz lalu menyodorkan kitabnya untuk dibaca agar didengar oleh kyai nya. Untuk santri lawas hanya membutuhkan waktu 5-10 menit, tapi untuk santri baru durasi waktunya bisa mencapai 10-15 menit karena dia belum faham dan belum menguasai bacaan kitab kuning. ${ }^{6}$

Langkah-langkah penerapan membaca kitab kuning dengan metode sorogan di Pondok Pesantren Mambaul Ulum diawali dengan membaca materi yang akan didengarkan oleh kyai/ustadz untuk dikoreksi kesalahan dan kekurangannya. Apabila masih ada santri yang bacaannya kliru atau masih ada kekurangan maka kyai/ustadz tidak menambah materi selanjutnya, sampai materi pertama benar-benar faham dan menguasai bacaan kitab kuning. Setelah materi pertama sudah dikuasai oleh santri, maka kyai/ustadz baru melanjutkan materi yang baru. Setelah selesai, para santri melanjutkan belajarnya di kamarnya masing-masing.

\section{Data Kemampuan Membaca Kitab Kuning Santri di Pondok Pesantren Mambaul Ulum}

Kemampuan membaca kitab kuning di pondok pesantren Mambaul Ulum ini saya ambil dari nilai hasil raport. Sebagaimana tabel dibawah ini.

Tabel 1. Nilai Hasil Raport Kelas 3 Ula dan 1 Wustho

\begin{tabular}{|c|l|c|}
\hline No & Nama Responden & Nilai \\
\hline 1 & M. Adin Saputra & 85 \\
\hline 2 & M Ikhsan Nashihuddin & 77 \\
\hline 3 & M. Zainul Mubaroq & 75 \\
\hline 4 & Syaiful Arif & 78 \\
\hline 5 & Ines Paradina & 77 \\
\hline 6 & Jenny Nur Azizah & 83 \\
\hline 7 & Juwita & 85 \\
\hline 8 & Reva Salsa Nabila & 75 \\
\hline 9 & Riska Aprilia & 85 \\
\hline 10 & Salwa Widyanati & 80 \\
\hline
\end{tabular}

\begin{tabular}{|c|l|c|}
\hline No & \multicolumn{1}{|c|}{ Nama Responden } & Nilai \\
\hline 11 & Wulan Widyanata & 85 \\
\hline 12 & Agus Afrizal & 75 \\
\hline 13 & Ahmad Dendi Setiyawan & 75 \\
\hline 14 & Ahmad Irvan & 75 \\
\hline 15 & Anggun Putra Jayadi & 75 \\
\hline 16 & Bilal Efendi & 85 \\
\hline 17 & M. Anton & 85 \\
\hline 18 & M. Riza Rahmawatinu & 90 \\
\hline 19 & M. Tajul Atok & 75 \\
\hline 20 & Muhammad Mahrul H. & 75 \\
\hline
\end{tabular}

\footnotetext{
${ }^{6}$ Hasil Observasi Pondok Pesantren Mambaul Ulum, pada tanggal 2 Mei 2019
} 


\begin{tabular}{|c|l|c|}
\hline 21 & Rispin Adi Nugroho & 85 \\
\hline 22 & Ayu Pardira & 70 \\
\hline 23 & Diya Rahmawati & 75 \\
\hline 24 & Ika Agustina & 80 \\
\hline 25 & Imroatul Khoiriyah & 70 \\
\hline
\end{tabular}

\begin{tabular}{|c|l|c|}
\hline 26 & Kamilatul Khoiria & 85 \\
\hline 27 & Melly Agustina & 85 \\
\hline 28 & Mia Nasikhah & 80 \\
\hline 29 & Muflikhatus Sa'adah & 75 \\
\hline 30 & Muhimmatus Sholikah & 85 \\
\hline
\end{tabular}

Tabel diatas menunjukkan bahwa kemampuan membaca kitab kuning santri kelas 3 ula dan 1 wustho dikategorikan sangat baik.

\section{A. Analisis Data}

\section{Pengolahan Data}

\section{a. Data Hasil Interview/wawancara}

Suatu pembelajaran bisa dikatakan dengan efektif, apabila tujuan dari proses belajar mengajar tercapai. Dalam mengajarkan suatu materi pelajaran guru/ustadz harus mampu menerapkan strategi, metode serta teknik yang sesuai dengan kemampuan dan karakteristik siswa. Hal ini sesuai dengan apa yang dikatakan Bapak KH. Hanif Abdurrahman selaku kepala yayasan pondok pesantren Mambaul Ulum Wadang Ngasem Bojonegoro ketika diinterview pada 8 Juni 2019.

"Memang dalam sebuah proses pembelajaran dapat berjalan dengan baik apabila ditunjang dengan berbagai strategi, metode serta teknik dalam penyampaiannya yang sesuai dengan materi ajar dan kebutuhan santri, salah satunya ya dengan menggunakan metode sorogan untuk mengetetahui keberhasilan santri dalam membaca kitab kuning. Dengan begitu santri juga akan lebih mudah dalam memahami kitab kuning". ${ }^{7}$

\section{b. Data Hasil Angket}

Pengolahan data dari hasil angket ini kami menyajikan dua data yaitu data tentang pengaruh metode sorogan dan data tentang keberhasilan membaca kitab kuning. Untuk mendapatkan data tersebut digunakan angket respon yang disebarkan kepada 30 santri Mambaul Ulum Wadang yakni 15 santri dari kelas 3 Ula dan 15 santri dari kelas 1 wustho. Yang terdiri dari 10 item pertanyaan tentang pengaruh metode sorogan dan nilai raport praktek membaca kitab fathul qorib.

\footnotetext{
${ }^{7}$ Hasil Wawancara Bapak KH. Hanif Abdurrahman.
} 
Adapun data yang diperoleh dari penyebaran angket ini masing-masing diberi 2 alternatif jawaban, kemudian dinilai dengan cara menjumlahkan dari setiap jawaban santri. Sebagai standar penulisan ditetapkan sebagai berikut:

1) Alternative "a" diberi skor 10 dengan kategori baik

2) Alternative "b" diberi skor 5 dengan kategori cukup baik

3) Jika tidak diisi diberi skor 0 dengan kategori kurang

Dan untuk menafsirkan hasil perhitungan dengan presentase, sebagai berikut:

1) $66 \%-100 \%$ tergolong baik

2) $37 \%$ - $65 \%$ tergolong kurang baik

3) Kurang dari $37 \%$ tergolong tidak baik

Data hasil angket pengaruh metode sorogan adalah sebagai berikut:

Tabel 2. Hasil Angket Pengaruh Metode Sorogan

\begin{tabular}{|l|c|c|c|c|c|c|c|c|c|c|c|}
\hline \multirow{2}{*}{$\begin{array}{l}\text { Responden } \\
\text { Nama }\end{array}$} & 1 & 2 & 3 & 4 & 5 & 6 & 7 & 8 & 9 & 10 & \multirow{2}{*}{ Jumlah } \\
\cline { 2 - 11 } $\begin{array}{l}\text { M. Adin } \\
\text { Saputra }\end{array}$ & 10 & 5 & 10 & 10 & 5 & 10 & 10 & 10 & 10 & 10 & 90 \\
\hline $\begin{array}{l}\text { M Ikhsan } \\
\text { Nashihuddin }\end{array}$ & 5 & 10 & 10 & 5 & 10 & 10 & 10 & 10 & 10 & 5 & 85 \\
\hline $\begin{array}{l}\text { M. Zainul } \\
\text { Mubaroq }\end{array}$ & 5 & 5 & 10 & 10 & 10 & 10 & 5 & 5 & 10 & 10 & 80 \\
\hline Syaiful Arif & 10 & 5 & 5 & 10 & 10 & 10 & 10 & 5 & 10 & 10 & 85 \\
\hline Ines Paradina & 10 & 10 & 10 & 5 & 5 & 10 & 10 & 5 & 10 & 10 & 85 \\
\hline $\begin{array}{l}\text { Jenny Nur } \\
\text { Azizah }\end{array}$ & 10 & 5 & 10 & 5 & 10 & 10 & 5 & 10 & 10 & 10 & 85 \\
\hline Juwita & 5 & 10 & 10 & 5 & 10 & 10 & 10 & 10 & 10 & 10 & 90 \\
\hline $\begin{array}{l}\text { Reva Salsa } \\
\text { Nabila }\end{array}$ & 10 & 5 & 10 & 5 & 10 & 10 & 5 & 10 & 10 & 10 & 85 \\
\hline Riska Aprilia & 10 & 5 & 5 & 10 & 5 & 10 & 10 & 10 & 10 & 5 & 80 \\
\hline $\begin{array}{l}\text { Salwa } \\
\text { Widyanati }\end{array}$ & 10 & 10 & 5 & 10 & 10 & 5 & 10 & 10 & 5 & 10 & 85 \\
\hline $\begin{array}{l}\text { Wulan } \\
\text { Widyanata }\end{array}$ & 10 & 5 & 10 & 5 & 10 & 10 & 10 & 10 & 10 & 10 & 90 \\
\hline Agus Afrizal & 5 & 5 & 5 & 10 & 10 & 10 & 10 & 10 & 10 & 10 & 85 \\
\hline
\end{tabular}




\begin{tabular}{|c|c|c|c|c|c|c|c|c|c|c|c|}
\hline $\begin{array}{l}\text { Ahmad } \\
\text { Dendi } \\
\text { Setiyawan }\end{array}$ & 5 & 10 & 10 & 10 & 5 & 10 & 5 & 10 & 10 & 5 & 80 \\
\hline Ahmad Irvan & 10 & 5 & 5 & 10 & 10 & 10 & 10 & 5 & 10 & 10 & 85 \\
\hline $\begin{array}{l}\text { Anggun } \\
\text { Putra Jayadi }\end{array}$ & 10 & 5 & 10 & 10 & 5 & 10 & 10 & 10 & 5 & 10 & 85 \\
\hline Bilal Efendi & 5 & 10 & 5 & 10 & 10 & 10 & 10 & 10 & 10 & 5 & 85 \\
\hline M. Anton & 10 & 10 & 10 & 10 & 5 & 10 & 10 & 5 & 10 & 10 & 90 \\
\hline $\begin{array}{l}\text { M. Riza } \\
\text { Rahmawatinu }\end{array}$ & 10 & 10 & 5 & 5 & 10 & 10 & 10 & 10 & 10 & 5 & 85 \\
\hline $\begin{array}{l}\text { M. Tajul } \\
\text { Atok }\end{array}$ & 10 & 5 & 10 & 10 & 5 & 5 & 10 & 5 & 10 & 10 & 80 \\
\hline $\begin{array}{l}\text { M. Mahrul } \\
\text { Hidayat }\end{array}$ & 10 & 10 & 5 & 10 & 5 & 10 & 5 & 10 & 10 & 10 & 85 \\
\hline $\begin{array}{l}\text { Rispin Adi } \\
\text { Nugroho }\end{array}$ & 10 & 5 & 10 & 10 & 10 & 10 & 10 & 10 & 10 & 5 & 90 \\
\hline Ayu Pardira & 10 & 5 & 10 & 5 & 10 & 10 & 10 & 10 & 5 & 10 & 85 \\
\hline $\begin{array}{l}\text { Diya } \\
\text { Rahmawati }\end{array}$ & 10 & 5 & 10 & 10 & 5 & 5 & 10 & 10 & 10 & 5 & 80 \\
\hline Ika Agustina & 10 & 10 & 5 & 10 & 5 & 10 & 5 & 10 & 10 & 10 & 85 \\
\hline $\begin{array}{l}\text { Imroatul } \\
\text { Khoiriyah }\end{array}$ & 5 & 10 & 10 & 10 & 5 & 10 & 10 & 10 & 5 & 10 & 85 \\
\hline $\begin{array}{l}\text { Kamilatul } \\
\text { Khoiria }\end{array}$ & 10 & 10 & 10 & 10 & 5 & 5 & 10 & 10 & 5 & 10 & 85 \\
\hline $\begin{array}{l}\text { Melly } \\
\text { Agustina }\end{array}$ & 10 & 10 & 5 & 5 & 10 & 10 & 10 & 10 & 10 & 10 & 90 \\
\hline $\begin{array}{l}\text { Mia } \\
\text { Nasikhah }\end{array}$ & 10 & 10 & 10 & 10 & 5 & 5 & 10 & 10 & 10 & 5 & 85 \\
\hline $\begin{array}{l}\text { Muflikhatus } \\
\text { Sa'adah }\end{array}$ & 5 & 10 & 5 & 10 & 10 & 5 & 5 & 10 & 10 & 10 & 80 \\
\hline $\begin{array}{l}\text { Muhimmatus } \\
\text { Sholikah }\end{array}$ & 10 & 10 & 5 & 10 & 10 & 10 & 5 & 10 & 10 & 5 & 85 \\
\hline
\end{tabular}

Dengan tabel di atas digunakan untuk menganalisis data kuantitatif dan menjawab rumusan masalah pertama yaitu tentang metode sorogan. Data yang ada pada tabel diatas maka dapat diketahui bahwa jumlah nilai metode sorogan atau nilai $\mathrm{X}$ yaitu sebesar 2550. Adapun nilai rata-ratanya sebagai berikut:

$$
\begin{aligned}
& \mathrm{M}=\frac{X}{Y} \\
& \mathrm{M}=\frac{2550}{30} \\
& \mathrm{M}=85
\end{aligned}
$$


Dari hasil perhitungan nilai rata-rata pengaruh metode sorogan / nilai variabel $\mathrm{X}$ adalah sebesar 85 ini berarti bahwa nilai rata-rata pengaruh metode sorogan yang diterapkan di pondok pesantren Mambaul Ulum Wadang Ngasem Bojonegoro di kategorikan sangat baik.

Selanjutnya disajikan data mengenai keberhasilan membaca kitab kuning atau variabel Y. Yang mana disini penulis akan mengambil data tersebut dari nilai raport praktek membaca kitab fathul qorib 15 anak dari kelas 3 Ula dan 15 anak dari kelas 1 Wustho di pondok pesantren Mambaul Ulum Wadang Ngasem Bojonegoro.

Tabel 3. Nilai Raport Santri Pondok Pesantren Mambaul Ulum Wadang Ngasem Bojonegoro Kelas 3 Ula dan 1 Wustho

\begin{tabular}{|c|l|c|}
\hline No & Nama Responden & Nilai \\
\hline 1 & M. Adin Saputra & 85 \\
\hline 2 & M Ikhsan Nashihuddin & 77 \\
\hline 3 & M. Zainul Mubaroq & 75 \\
\hline 4 & Syaiful Arif & 78 \\
\hline 5 & Ines Paradina & 77 \\
\hline 6 & Jenny Nur Azizah & 83 \\
\hline 7 & Juwita & 85 \\
\hline 8 & Reva Salsa Nabila & 75 \\
\hline 9 & Riska Aprilia & 85 \\
\hline 10 & Salwa Widyanati & 80 \\
\hline 11 & Wulan Widyanata & 85 \\
\hline 12 & Agus Afrizal & 75 \\
\hline 13 & Ahmad Dendi Setiyawan & 75 \\
\hline 14 & Ahmad Irvan & 75 \\
\hline 15 & Anggun Putra Jayadi & 75 \\
\hline
\end{tabular}

\begin{tabular}{|c|l|c|}
\hline No & Nama Responden & Nilai \\
\hline 16 & Bilal Efendi & 85 \\
\hline 17 & M. Anton & 85 \\
\hline 18 & M. Riza Rahmawatinu & 90 \\
\hline 19 & M. Tajul Atok & 75 \\
\hline 20 & Muhammad Mahrul H & 75 \\
\hline 21 & Rispin Adi Nugroho & 85 \\
\hline 22 & Ayu Pardira & 70 \\
\hline 23 & Diya Rahmawati & 75 \\
\hline 24 & Ika Agustina & 80 \\
\hline 25 & Imroatul Khoiriyah & 70 \\
\hline 26 & Kamilatul Khoiria & 85 \\
\hline 27 & Melly Agustina & 85 \\
\hline 28 & Mia Nasikhah & 80 \\
\hline 29 & Muflikhatus Sa'adah & 75 \\
\hline 30 & Muhimmatus S. & 85 \\
\hline
\end{tabular}


Dari data yang ada pada tabel diatas, dapat diketahui bahwa nilai hasil angket keberhasilan membaca kitab kuning adalah 2385. Jadi nilai variabel Y adalah sebesar 2385. Adapun nilai rata-ratanya adalah:

$$
\begin{aligned}
& \mathrm{M}=\frac{X}{Y} \\
& \mathrm{M}=\frac{2385}{30} \\
& \mathrm{M}=79,5
\end{aligned}
$$

Dari perhitungan nilai rata-rata keberhasilan membaca kitab kuning santri pondok pesantren mambaul ulum wadang ngasem bojonegoro / nilai rata-rata variabel Y adalah sebesar 79,5. Ini berarti nilai rata-rata keberhasilan membaca kitab kuning dikategorikan baik.

\section{Analisis Statistik}

Untuk mengetahui pengaruh/tidaknya metode sorogan terhadap keberhasilan membaca kitab kuning santri di pondok pesantren mambaul ulum wadang ngasem bojonegoro, terlebih dulu akan dicari hubungan dari kedua variabel tersebut dengan menggunakan rumus product moment.

$$
r_{x y}=\frac{N \sum X Y-\left(\sum X\right)\left(\sum Y\right)}{\left.\sqrt{\{N} X^{2}-\left(\sum X\right)^{2}\right\}\left\{N\left(\sum Y^{2}-\left(\sum Y\right)^{2}\right\}\right.}
$$

Keterangan :

$r_{x y} \quad$ : Angka indeks kolerasi " $r$ " product moment

$N \quad$ : jumlah responden

$\sum X \quad$ : Jumlah seluruh skor $\mathrm{X}$

$\sum Y \quad$ : Jumlah seluruh skor $Y$

$\sum X^{2} \quad$ :Jumlah hasil perkalian kuadrat skor $\mathrm{X}$

$\sum Y^{2}$ : Jumlah hasil perkalian kuadrat skor $\mathrm{Y}$

$\sum X Y \quad$ : Jumlah hasil perkalian antara skor $\mathrm{X}$ dan skor $\mathrm{Y}$ 
Sesudah mendapatkan nilai pengaruh metode sorogan dan keberhasilan membaca kitab kuning santri pondok pesantren Mambaul Ulum Wadang Ngasem Bojonegoro. Maka selanjutnya adalah melaksanakan analisis data untuk mengetahui ada tidaknya pengaruh metode sorogan terhadap keberhasilan membaca kitab kuning santri pondok pesantren Mambaul Ulum Wadang Ngasem Bojonegoro. Analisis data ini bertujuan untuk menguji kebenaran hipotesis yang telah penulis ajukan dalam penulisan skripsi ini apakah di tolak apa diterima.

Untuk menguji hipotesis tersebut penulis menggunkaam teknik setatistik dengan rumus prodact moment. Sedangkan langkah-lamgkah sebagai berikut:

1. Membuat tebel kerja correlation prodact moment.

2. Memasukkan nilai pengunaan metode sorogan pada kolom $X$, dan nilai keberhasilan membaca kitab kuning pada kolom Y.

3. Memasukan nilai kuadrat nilai penggunaan metode sorogan pada kolom $X^{2}$ dan nilai keberhasilan membaca kitab kuning pada kolom $\mathrm{Y}^{2}$.

4. Memasukkan hasil perkalian antara nilai penggunaan metode sorogan dan nilai keberhasilan membaca kitab kuning pada kolom XY

5. menghitung koefisien korelasi

6. koefisien koreklasi yang di peroleh di kondisikan dengan harga kritik pada tabel "r" (correlation prodact moment)

7. menarik kesimpulan

berpijak pada langkah-langkah di atas, dapatlah di sajikan pengolahan data sebagai berikut:

Tabel 5. Perhitungan Pengaruh Metode Sorogan Terhadap Kemampuan Membaca Kitab Kuning Santri Pondok Pesantren Mambaul Ulum Wadang Ngasem Bojonegoro

\begin{tabular}{|c|c|c|c|c|c|}
\hline No & $\mathbf{X}$ & $\mathbf{Y}$ & $\mathbf{X}^{\mathbf{2}}$ & $\mathbf{Y}^{\mathbf{2}}$ & $\mathbf{X Y}$ \\
\hline 1 & 90 & 85 & 8100 & 7225 & 7650 \\
\hline 2 & 85 & 70 & 7225 & 4900 & 5950 \\
\hline 3 & 80 & 75 & 6400 & 5625 & 6000 \\
\hline 4 & 85 & 80 & 7225 & 6400 & 6800 \\
\hline 5 & 85 & 70 & 7225 & 4900 & 5950 \\
\hline
\end{tabular}




\begin{tabular}{|c|c|c|c|c|c|}
6 & 85 & 90 & 7225 & 8100 & 7650 \\
\hline 7 & 90 & 85 & 8100 & 7225 & 7650 \\
\hline 8 & 85 & 90 & 7225 & 8100 & 7650 \\
\hline 9 & 80 & 70 & 6400 & 4900 & 5600 \\
\hline 10 & 85 & 80 & 7225 & 6400 & 6800 \\
\hline 11 & 90 & 85 & 8100 & 7225 & 7650 \\
\hline 12 & 85 & 70 & 7225 & 4900 & 5950 \\
\hline 13 & 80 & 75 & 6400 & 5625 & 6000 \\
\hline 14 & 85 & 80 & 7225 & 6400 & 6800 \\
\hline 15 & 85 & 70 & 7225 & 4900 & 5950 \\
\hline 16 & 85 & 90 & 7225 & 8100 & 7650 \\
\hline 17 & 90 & 85 & 8100 & 7225 & 7650 \\
\hline 18 & 85 & 90 & 7225 & 8100 & 7650 \\
\hline 19 & 80 & 70 & 6400 & 4900 & 5600 \\
\hline 20 & 85 & 80 & 7225 & 6400 & 6800 \\
\hline 21 & 90 & 85 & 8100 & 7225 & 7650 \\
\hline 22 & 85 & 70 & 7225 & 4900 & 5950 \\
\hline 23 & 80 & 75 & 6400 & 5625 & 6000 \\
\hline 24 & 85 & 80 & 7225 & 6400 & 6800 \\
\hline 25 & 85 & 70 & 7225 & 4900 & 5950 \\
\hline 26 & 85 & 90 & 7225 & 8100 & 7650 \\
\hline 27 & 90 & 85 & 8100 & 7225 & 7650 \\
\hline 28 & 85 & 90 & 7225 & 8100 & 7650 \\
\hline 29 & 80 & 70 & 6400 & 4900 & 5600 \\
\hline 30 & 85 & 80 & 7225 & 6400 & 6800 \\
\hline & 2550 & 2385 & 217050 & 191325 & 203100 \\
\hline
\end{tabular}

Berdasarkan data-data yang ada pada tabel di atas, dapat di ketahui bahwa:

1. jumlah $\mathrm{N} /$ responden adalah 30

2. jumlah nilai metode sorogan $\sum X$ Sebesar 2550

3. jumlah nilai keberhasilan membaca kitab kuning $\sum Y$ sebesar 2385

4. jumlah nilai $\sum X^{2}$ sebesar 217050

5. jumlah nilai $\sum Y^{2}$ sebesar 191325

6. Jumlah nilai perkalian $\sum X Y$ sebesar 203100 
Kemudian dari nilai tersebut, di masuk kan dalam rumus prodact moment, yaitu:

$$
\begin{aligned}
& r_{x y}=\frac{N \sum X Y-\left(\sum X\right)\left(\sum Y\right)}{\sqrt{\left\{N X^{2}-\left(\sum X\right)^{2}\right\}\left\{N\left(\sum Y^{2}-\left(\sum Y\right)^{2}\right\}\right.}} \\
& r_{x y}=\frac{30 x 203100-(2550 x 2385)}{\sqrt{\left\{\left(30 x 217050-(2550)^{2}\left(30 x 191325-(2385)^{2}\right\}\right.\right.}} \\
& r_{x y}=\frac{6093000-6081750}{\sqrt{\{(6511500-6502500)(5739750-5688225)\}}} \\
& r_{x y}=\frac{11250}{\sqrt{\{(9000)(51525)\}}} \\
& r_{x y}=\frac{11250}{\sqrt{\{463725000\}}} \\
& r_{x y}=\frac{11250}{21534,275} \\
& r_{x y}=0,522
\end{aligned}
$$

Telah diketahui bahwa $r_{o}=0,522$. Dengan $N=30$ dan pada taraf signifikasi $5 \%$ $r_{t}=0,361$. Sedang pada taraf siginifikasi $1 \% r_{t}=0,462$. Dengan demikian pada taraf signifikan $5 \% r_{o}>r_{t}(0,522>0,361)$. Demikan pula pada taraf signifikasi $1 \% r_{0}>r_{t}$ $(0,522>0,462)$. Jadi pada taraf signifikasi $1 \%$ ataupun $5 \%$ hipotesis yang peneliti ajukan dapat di terima. Ini berarti hipotesis kerja $\left(\mathrm{H}_{\mathrm{a}}\right)$ di terima dan hipotesis nihil $\left(\mathrm{H}_{\mathrm{o}}\right)$ di tolak. Ini berarti antara variabel $\mathrm{X}$ dan $\mathrm{Y}$ terdapat korelasi positif. Ini berarti hipotesis kerja yang menyatakan adanya korelasi antara variabel $\mathrm{X}$ dan $\mathrm{Y}$ itu benar. Artinya metode sorogan berpengaruuh terhadap keberhasilan membaca kitab kuning santri Pondok Pesantren Mambaul Ulum Wadang Ngasem Bojonegoro.

\section{KESIMPULAN}

Dari hasil penelitian yang telah dilakukan oleh penulis pada pembelajaran membaca kitab fathul qorib dengan metode sorogan di Pondok Pesantren Mambaul Ulum, dapat diambil kesimpulan sebagai berikut: 
1. Metode sorogan yang diterapkan di pondok pesantren Mambaul Ulum ini santri maju satu persatu dihadapan ustadz kemudian meyodorkan kitab yang telah dipelajari sebelumnya. Sedangkan ustadz menyimak hanya menyimak, jika ada yang terjadi kesalahan langsung dibenarkan, setelah itu santri menjelaskan maksud dari bacaannya dan ustadz mengajukan pertanyaan dari teks yang telah dibaca tersebut.

2. Adapun faktor utama yang mendukung keberhasilan membaca kitab santri dengan menggunakan metode sorogan adalah penguasaan santri terhadap teori nahwu shorof untuk membaca kitab kuning dan penguasaan mufrodat (perbendaharaan kosa kata). Sedangkan faktor yang menghambat keberhasilan membaca kitab kuning santri yaitu kurangnya pemahaman santri terhadap materi dan membutuhkan waktu yang relatif lama.

3. Ada pengaruh metode sorogan terhadap kemampuan membaca kitab kuning santri di pondok pesantren Mambaul Ulum. Pada taraf signifikan 5\% $r_{o}>r_{t}$ $(0,522>0,361)$. Demikan pula pada taraf signifikasi $1 \% r_{0}>r_{t}(0,522>0,462)$. Jadi pada taraf signifikasi $1 \%$ ataupun $5 \%$ hipotesis yang peneliti ajukan dapat di terima. Ini berarti hipotesis kerja $\left(\mathrm{H}_{\mathrm{a}}\right)$ di terima dan hipotesis nihil $\left(\mathrm{H}_{\mathrm{o}}\right)$ di tolak. Ini berarti antara variabel $\mathrm{X}$ dan $\mathrm{Y}$ terdapat korelasi positif.

\section{DAFTAR PUSTAKA}

Abdurrahman. 1990. Pesantren Masa Depan, Wacana Pemberdayaan dan Transformasi Pesantren. Bandung : Pustaka Hidayah.

Departemen Agama RI. 2006. Al-Qur'an dan Tafsirnya. Jakarta:Departemen Agama RI.

Hakim, Taufiqul. 2003. Metode Praktis Mendalami Al-Qur'an dan Membaca Kitab Kuning. Bandung : Mizan.

Hermawan, Asep. 2011. Metodologi Pembelajaran Bahasa Arab. Bandung : PT. Remaja Roesdakarya.

Ismail. 2008. Strategi Pembelajaran Agama Islam. Semarang : Rasail Media Group.

Suyono. 2011. Belajar dan Pembelajaran. Bandung: PT Remaja Rosdakarya. 